\title{
Source and Health Risk Assessment of Heavy Metals in Soil-Ginger System in the Jing River Basin of Shandong Province, North China
}

\author{
Songtao Wang ${ }^{1,2}$, Zongjun Gao ${ }^{3}$, Yuqi Zhang ${ }^{3, *}$, Hairui Zhang ${ }^{1,2}$, Zhen Wu ${ }^{1,2}$, Bing Jiang ${ }^{1,2}$, Yang Liu ${ }^{1,2}$ \\ and Hongzhi Dong ${ }^{3}$
}

1 The Fourth Geological Brigade of Shandong Provincial Bureau of Geology and Mineral Resources, Weifang 261021, China; wangsongtao@sddksy.com (S.W.); zhanghairui@sddksy.com (H.Z.); wuzhen@sddksy.com (Z.W.); jiangbing@sddksy.com (B.J.); liuyang@sddksy.com (Y.L.)

2 Key Laboratory of Coastal Zone Geological Environment Protection of Shandong Geology and Mineral Exploration and Development Bureau, Weifang 261021, China

3 College of Earth Science and Engineering, Shandong University of Science and Technology, Qingdao 266590, China; zongjungao1964@163.com (Z.G.); dhz@sdust.edu.cn (H.D.)

* Correspondence: zyq_skd@sdust.edu.cn; Tel.: +86-18863978186

check for updates

Citation: Wang, S.; Gao, Z.; Zhang, Y.; Zhang, H.; Wu, Z.; Jiang, B.; Liu, Y.; Dong, H. Source and Health Risk Assessment of Heavy Metals in Soil-Ginger System in the Jing River Basin of Shandong Province, North China. Int. J. Environ. Res. Public Health 2021, 18, 6749. https:// doi.org/10.3390/ijerph18136749

Academic Editor: Jorge Paz-Ferreiro

Received: 27 April 2021

Accepted: 17 June 2021

Published: 23 June 2021

Publisher's Note: MDPI stays neutral with regard to jurisdictional claims in published maps and institutional affiliations.

Copyright: (c) 2021 by the authors. Licensee MDPI, Basel, Switzerland. This article is an open access article distributed under the terms and conditions of the Creative Commons Attribution (CC BY) license (https:// creativecommons.org/licenses/by/ $4.0 /)$.
Abstract: This study investigated the characteristics and sources of heavy metals in a soil-ginger system and assessed their health risks. To this end, 321 topsoil samples and eight soil samples from a soil profile, and 18 ginger samples with root-soil were collected from a ginger-planting area in the Jing River Basin. The average concentration of heavy metals in the topsoil followed the order: $\mathrm{Cr}>\mathrm{Zn}>\mathrm{Pb}>\mathrm{Ni}>\mathrm{Cu}>\mathrm{As}>\mathrm{Cd}>\mathrm{Hg}$. In the soil profile, at depths greater than $80 \mathrm{~cm}$, the contents of $\mathrm{Cr}, \mathrm{Ni}$, and $\mathrm{Zn}$ tended to increase with depth, which may be related to the parent materials, whereas $\mathrm{As}$ and $\mathrm{Cu}$ contents showed little change. In contrast, $\mathrm{Pb}$ content decreased sharply from top to bottom, which may be attributable to external environmental and anthropogenic factors. Multivariate statistical analysis showed that $\mathrm{Cr}, \mathrm{Ni}, \mathrm{Cu}, \mathrm{Zn}$, and $\mathrm{Cd}$ contents in soil are affected by natural sources, $\mathrm{Pb}$ and As contents are significantly affected by human activities, and $\mathrm{Hg}$ content is affected by farmland irrigation. Combined results of the single pollution index $\left(P_{i}\right)$, geo-accumulation index $\left(I_{\text {geo }}\right)$, and potential ecological risk assessment $\left(E_{i}\right.$ and $\left.R I\right)$ suggest that soil in the study area is generally not polluted by heavy metals. In ginger, $\mathrm{Zn}$ content was the highest $(2.36 \mathrm{mg} / \mathrm{kg})$ and $\mathrm{Hg}$ content was the lowest $(0.0015 \mathrm{mg} / \mathrm{kg})$. Based on the bioconcentration factor, $\mathrm{Cd}$ and $\mathrm{Zn}$ have high potential for enrichment in ginger. With reference to the limit of heavy metals in tubers, $\mathrm{Cr}$ content in ginger exceeds the standard in the study area. Although $\mathrm{Cr}$ does not accumulate in ginger, $\mathrm{Cr}$ enrichment in soil significantly increases the risk of excessive $\mathrm{Cr}$ content in ginger.

Keywords: heavy metals; soil; ginger; health risk assessment; Jing River Basin

\section{Introduction}

Heavy metals, which generally include $\mathrm{As}, \mathrm{Cr}, \mathrm{Cd}, \mathrm{Pb}$, and other biotoxic elements, are persistent pollutants that continuously accumulate in the environment. These pollutants accumulate in soil through various sources, such as industrial activities, fertilization and irrigation, and rock weathering [1]. Heavy metals in soil can be taken up by plants and then reach the human body through the food chain, seriously threatening human life and health [2-4]. With their long biological half-lives, nonbiodegradability, and ability to chronically accumulate in different parts of the body, such as the kidneys and liver, heavy metals are extremely harmful [5]. In appropriate amounts, trace metals, such as $\mathrm{Cu}, \mathrm{Zn}, \mathrm{Fe}, \mathrm{Mn}$, and $\mathrm{Cr}$, play an important role in enzyme structuring and the synthesis of hemoglobin and vitamins, but excess contents of these metals can be harmful. In contrast, heavy metals such as $\mathrm{Cd}$ and $\mathrm{Pb}$ are toxic, even at low concentrations [6]. Therefore, it is of 
great significance to identify the characteristics, distribution, and sources of heavy metals in soil-crop systems and conduct associated health risk assessments.

Determining the source of heavy metals is key to preventing and controlling heavy metal pollution. Multivariate statistical analyses have been widely used to trace the source of heavy metals, and factor analysis (FA) and hierarchical clustering analysis (HCA) have commonly been employed [7-10]. FA is advantageous in that it uses a small number of variables to explain complex problems. Using R-type HCA, variables with large differences can be separated and similar variables can be clustered. Huang et al. [11] quantified the contribution of each heavy metal source using FA combined with absolute principal component scores/multiple linear regression (APCS-MLR), considering that natural sources contribute the most to $\mathrm{Cr}, \mathrm{Ni}$, and $\mathrm{Cu}$ contents, agricultural activities contribute the most to $\mathrm{Zn}, \mathrm{Cd}$, and $\mathrm{Pb}$ contents, industrial emissions contribute the most to As content, and coal burning contributes the most to $\mathrm{Hg}$ content, with other possible unknown sources, such as traffic or domestic sewage. Sun [12] performed HCA on heavy metal contents in roots, stems, and leaves of tea trees in Tieguanyin Tea Garden in the southeast of Fujian Province and suggested that the results of HCA are consistent with those of FA.

Over the past few decades, environmental scientists have developed a number of methods for assessing heavy metal pollution. Classical index evaluation methods include single pollution index $\left(P_{i}\right)$ [13], geo-accumulation index $\left(I_{\text {geo }}\right)$ [14], and potential ecological risk assessment method $\left(E_{i}\right.$ and $\left.R I\right)$ [15]. The $P_{i}$ method reflects the pollution of heavy metals in soil by comparing observed values with standard limit values. The $I_{g e o}$ method is based on the geochemical background values of heavy metals, using the logarithmic evaluation results, and considering the correction coefficient of changes in background values, which may be caused by diagenetic factors; this approach is more intuitive for evaluating samples with relatively high contamination levels. The Ei and RI methods eliminate differences attributable to background values of elements and comprehensively reflect the impact of heavy metals on the ecological environment from the three major aspects of ecology, environment, and toxicology; accordingly, these methods have a wide range of applicability [16-22].

Ginger is a common spice in daily food and is also a known medicinal plant [23]. Heavy metals in soil significantly affect the growth of ginger. Li et al. [24] suggested that a $\mathrm{Pb}$ content of $250 \mathrm{mg} / \mathrm{kg}$ in soil slightly promoted the growth of ginger, but $\mathrm{Pb}$ contents of $500-1000 \mathrm{mg} / \mathrm{kg}$ significantly inhibited its growth. As ginger is directly ingested by humans, some heavy and trace metals with potential long-term health risks may be indirectly taken up. Therefore, the study of heavy metals in ginger is of great significance. A standardized production base of ginger has been established in villages along the Jing River in Shandong Province. With its thin rind, bright yellow color, and strong flavor, ginger from this region has been sold not only within China, but also to more than 10 countries.

In this study, the contents of $\mathrm{Cr}, \mathrm{Ni}, \mathrm{Cu}, \mathrm{Zn}, \mathrm{Cd}, \mathrm{Pb}, \mathrm{As}$, and $\mathrm{Hg}$ in a soil-ginger system in the Jing River Basin were analyzed with the following aims: (1) to trace the potential sources of heavy metals; (2) to assess the health risks of heavy metals in the soil-ginger system. The results of this study can provide insights for the prevention and control of local soil heavy metal pollution, and scientific planting of ginger.

\section{Materials and Methods}

\subsection{Study Area}

The study area, located in Weifang City, Shandong Province, is a standardized ginger planting area established along the Jing River, the main tributary of the Qu River (Figure 1). It is located in the north temperate monsoon climate zone, with four distinct seasons. The mean annual precipitation is approximately $740 \mathrm{~mm}$, of which the months of June, July, and August account for approximately $60-70 \%$. In the study area, brown soil with high clay content and low organic matter is widely distributed in most areas west of Shiqiaozi Town. In the area east of Shiqiaozi Town, the soil type is leached cinnamon soil, and the parent material is mainly composed of residual deposits and pluvial alluvial deposits of 
limestone, sandstone, and shale. A small part of the area features neutral skeleton soil with darker color.
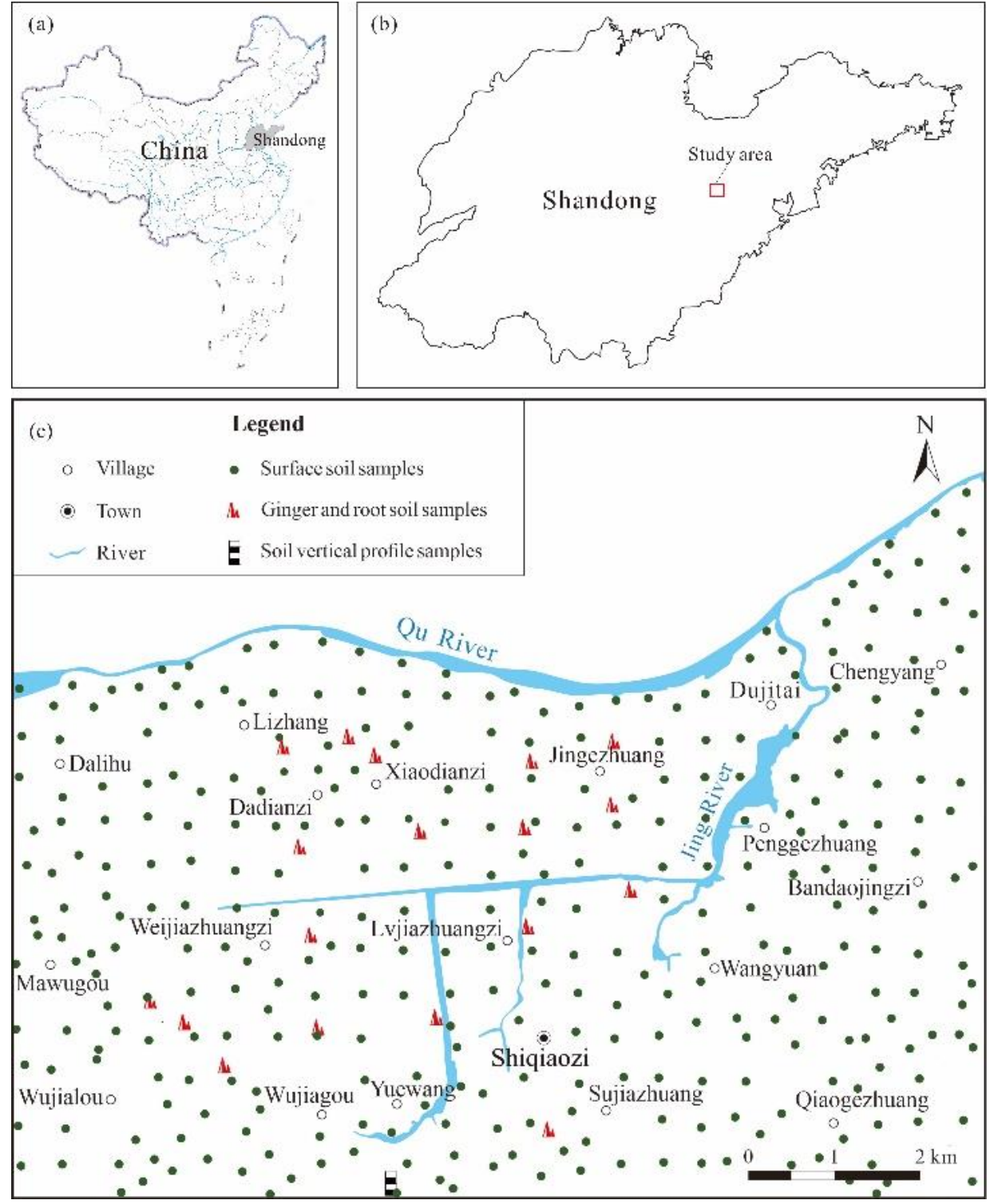

Figure 1. Location map of the study area (a) Location of Shandong Province (b) Location of the study area (c) Sampling location.

\subsection{Data Source}

Geochemical data of soil and ginger used in the present study were provided by the Fourth Geological Brigade of Shandong Provincial Bureau of Geology and Mineral Resources. The sampling site is located in the ginger-planting area of the Jing River Basin in Shandong Province. The land-use type is mainly cultivated land, with problems such as excessive irrigation. In addition, the development of machinery foundry, building materials, and other enterprises in the study area has improved the economic performance, but also significantly increased the amount of sewage discharge. This led to an increase in the content of heavy metals, some of which may have accumulated in crops, such as ginger.

In October 2018, 321 topsoil samples, 8 soil samples from a soil profile, and 18 ginger samples with root-soil were collected from the study area. Sampling points of surface soil were laid out in grids of $1 \times 1 \mathrm{~km}$, and the average sampling density of soil samples was 5.5 pieces $/ \mathrm{km}^{2}$. The depth of the soil profile was $2 \mathrm{~m}$; one sample was collected every $0.2 \mathrm{~m}$ 
within $0-1 \mathrm{~m}$, and samples were collected at $1.3,1.6$, and $2.0 \mathrm{~m}$ within 1-2 $\mathrm{m}$. Soil samples were air dried at $25{ }^{\circ} \mathrm{C}$, broken with a wooden stick, and sieved through a 10-mesh sift. Ginger samples were collected in the peak harvest period. Sampling units of $0.1-0.2 \mathrm{hm}^{2}$ were set, and 5-20 ginger samples were collected from each sampling unit. The samples were then mixed in equal amounts to form a mixed sample. The ginger samples were rinsed in the fresh state to remove adhered soil and contamination by fertilization and spraying of pesticides, and then dried at room temperature.

All samples were sent to the Experimental Testing Center of the Fourth Geological Brigade of Shandong Provincial Bureau of Geology and Mineral Resources for testing. Heavy metals were determined according to the Specification of Multi-purpose Regional Geochemical Survey (1:250,000) (DZ/T 0258-2014), Specification of Regional Ecogeochemistry Assessment (DZ/T 0289-2015), Technical Requirements for Analysis of Ecological Geochemical Evaluation Samples (Trial), and the Specification of Testing Quality Management for Geological Laboratories (DZ/T 0130.4-2006). For Cd analysis, samples were dissolved in $\mathrm{HF}, \mathrm{HNO}_{3}$, and $\mathrm{HClO}_{4}$ to catch fluorine, and extracted with $\mathrm{HNO}_{3}$; the volume was metered and $\mathrm{Cd}$ was then determined by inductively coupled plasma mass spectrometry (ICP-MS). For $\mathrm{Cu}, \mathrm{Pb}, \mathrm{Zn}, \mathrm{Ni}$, and $\mathrm{Cr}$, samples were processed using the powder pressure method and tested by X-ray fluorescence spectrometry (XRF). For As and Hg, samples were pretreated with aqua regia and tested by atomic fluorescence spectrometry (AFS). For $\mathrm{pH}$, samples were immersed in distilled water without carbon dioxide and tested using the ion selective electrode (ISE) method.

To ensure strict quality assurance and control procedures, 4 national first-level reference materials (GBW) (internal quality control) and 2 external standard control samples (external quality control) were inserted for every 50 samples, and their accuracy and precision were $100 \%$ qualified. At the same time, 2 replicate samples were set for every 50 samples for repeatability inspection. The pass rate of each index was between $96.2 \%$ and $99.1 \%(>90 \%)$, which meets test quality requirements of the "Specification of Land Quality Geochemical Assessment" (DZ/T 0295-2016).

\subsection{Data Analysis}

The basic data were analyzed in Microsoft Excel, and the statistical analyses of soil physical and chemical properties and heavy metal contents were performed in SPSS 25 (Chicago, IL, USA). A diagram of heavy metal contents in the soil profile was drawn in Origin 7.5 (Northampton, MA, USA) to reflect their distribution.

FA is the most commonly used method of dimensionality reduction, which can be used to reduce the multi-element heavy metal dataset to 3-4 factors, and then determine the potential sources of heavy metals by determining the source of each factor. FA requires a strong correlation between the original variables, which is usually determined using the KMO test and Bartlett's test. If the KMO test coefficient is greater than 0.5, and the $p$ value (significance probability) of Bartlett's Test is less than 0.05 , the data is suitable for FA. R-type HCA was used to classify heavy metals, such that each category can represent certain characteristics, which can verify the results of FA. Correlation analysis was applied to describe the closeness between two variables, and then reveal the synergistic and antagonistic effects between heavy metals.

The bioconcentration factor (BCF) is the ratio of the content of a certain element in plants to the content of that element in soil (Equation (1)), which reflects the ability of the metal to migrate from the soil to the plant to a certain extent [25-28].

$$
B C F=C_{i-\text { ginger }} / C_{i-\text { soil }}
$$

where $C_{i \text {-ginger }}$ is the measured concentration of the $i$ th heavy metal in ginger; $C_{i \text {-soil }}$ is the measured concentration of heavy metal $i$ in root-soil.

$P_{i}, I_{g e o}, E_{i}$, and $R I$ are commonly used indices for the evaluation of soil heavy metal pollution $[29,30]$. The equations and degrees of these indices are shown in Table 1. 
Table 1. Classification of $P_{i}, I_{g e o}, E_{i}$ and RI.

\begin{tabular}{|c|c|c|c|c|}
\hline Index & Equation & & Category & Degree \\
\hline \multirow{5}{*}{$\begin{array}{l}\text { Single pollution index } \\
\qquad\left(P_{i}\right)\end{array}$} & \multirow{3}{*}{$P_{i}=C_{i} / C_{t i}$} & \multirow{3}{*}{ (2) } & $P_{i}<0.7$ & Nonpollution (soil), clean (crop) \\
\hline & & & $0.7 \leq P_{i}<1$ & $\begin{array}{l}\text { Nonpollution (soil), slightly clean } \\
\text { (crop) }\end{array}$ \\
\hline & & & $1 \leq P_{i}<2$ & $\begin{array}{l}\text { Slight pollution (soil), moderate } \\
\text { pollution (crop) }\end{array}$ \\
\hline & \multirow{8}{*}{$\begin{array}{c}I_{g e o}= \\
\log _{2}\left(C_{i} / 1.5 C_{b i}\right)\end{array}$} & \multirow{8}{*}{ (3) } & $2 \leq P_{i}<3$ & Moderate pollution (soil and crop) \\
\hline & & & $\bar{P}_{i} \geq 3$ & Heavy pollution (soil and crop) \\
\hline \multirow{6}{*}{$\begin{array}{l}\text { Geo-accumulation } \\
\text { index }\left(I_{g e o}\right)\end{array}$} & & & $I_{g e o}<0$ & Nonpollution \\
\hline & & & $0 \leq I_{\text {geo }}<1$ & Slight pollution \\
\hline & & & $1 \leq I_{\text {geo }}<2$ & Moderate pollution \\
\hline & & & $2 \leq I_{g e o}<3$ & Moderate to heavy pollution \\
\hline & & & $3 \leq I_{\text {geo }}<4$ & Heavy pollution \\
\hline & & & $4 \leq I_{\text {geo }}<5$ & Heavy to extreme pollution \\
\hline \multirow{5}{*}{$\begin{array}{l}\text { Potential ecological risk } \\
\text { assessment method }\left(E_{i}\right. \\
\text { and } R I)\end{array}$} & \multirow{5}{*}{$\begin{array}{c}E_{i}=T_{i} \times C_{i} / C_{b i} \\
R I=\sum_{i=1}^{n} E_{i}\end{array}$} & \multirow{5}{*}{$\begin{array}{l}(4) \\
(5)\end{array}$} & $\begin{array}{c}I_{\text {geo }} \geq 5 \\
E_{i}<40 ; R I<150\end{array}$ & $\begin{array}{c}\text { Extreme pollution } \\
\text { Low potential ecological risk }\end{array}$ \\
\hline & & & $40 \leq E_{i}<80 ; 150 \leq R I<300$ & Moderate potential ecological risk \\
\hline & & & $80 \leq E_{i}<160 ; 300 \leq R I<600$ & Considerable potential ecological risk \\
\hline & & & $\begin{array}{c}160 \leq E_{i}<320 ; R I \geq 600 \\
E_{i}>320\end{array}$ & $\begin{array}{l}\text { High potential ecological risk } \\
\text { Extreme potential ecological risk }\end{array}$ \\
\hline & & & $L_{i}-6<0$ & Extreme potential ecological risk \\
\hline
\end{tabular}

$C_{i}$ : measured concentration of the $i$ th heavy metal; $C_{t i}$ : the limit value of the $i$ th heavy metal; $C_{b i}$ : background value of the $i$ th heavy metal; $E_{i}$ : single-factor potential ecological risk index of the $i$ th heavy metal; $T_{i}$ : toxicity coefficient of the $i$ th heavy metal; $R I$ : the comprehensive ecological risk of the $i$ th heavy metal.

\section{Results and Discussion}

\subsection{Soil Geochemistry}

\subsubsection{Average Concentration of Heavy Metals}

The $\mathrm{pH}$ value of surface soil in the ginger-planting area ranged from 4.24 to 7.72 , showing weakly acidic-neutral soil. The average concentrations of heavy metals followed the order: $\mathrm{Cr}>\mathrm{Zn}>\mathrm{Pb}>\mathrm{Ni}>\mathrm{Cu}>\mathrm{As}>\mathrm{Cd}>\mathrm{Hg}$ (Table 2). The coefficient of variance (CV) is an important parameter that reflects elemental distribution. The $\mathrm{CV}$ values of $\mathrm{Cr}, \mathrm{Zn}, \mathrm{Pb}$, $\mathrm{Ni}, \mathrm{Cu}$, As, and $\mathrm{Cd}$ ranged from 0.12 to 0.37 , indicating a relatively uniform distribution. In contrast, the $\mathrm{CV}$ value of $\mathrm{Hg}$ was 0.57 , reflecting an uneven distribution. The contents of $\mathrm{Cd}, \mathrm{Zn}, \mathrm{Ni}, \mathrm{Cu}$, and $\mathrm{As}$ in soil were below the reference background values of Shandong. The contents of $\mathrm{Cr}, \mathrm{Hg}$, and $\mathrm{Pb}$ in the study area were relatively high at 1.08-1.09 times those of their averages in the province, reflecting relatively high levels of pollution.

Table 2. Statistical characteristics of heavy metal contents in surface soil (mg/kg).

\begin{tabular}{cccccccccc}
\hline Data & $\mathbf{C r}$ & $\mathbf{N i}$ & $\mathbf{C u}$ & $\mathbf{Z n}$ & $\mathbf{A s}$ & $\mathbf{C d}$ & $\mathbf{H g}$ & $\mathbf{P b}$ & $\mathbf{p H}$ \\
\hline Mean & 66.92 & 25.04 & 19.4 & 51.68 & 6.4 & 0.1 & 0.03 & 25.65 & 6.21 \\
Minimum & 48.1 & 14.9 & 7.5 & 32.1 & 3.32 & 0.06 & 0.01 & 16.1 & 4.24 \\
Maximum & 92.1 & 39.4 & 47.6 & 83.7 & 11.16 & 0.24 & 0.17 & 81.2 & 7.72 \\
CV & 0.12 & 0.18 & 0.37 & 0.18 & 0.21 & 0.25 & 0.57 & 0.28 & 0.1 \\
Shandong background value & 62 & 27.1 & 22.6 & 63.3 & 8.6 & 0.13 & 0.03 & 23.6 & 7.32 \\
K & 1.08 & 0.92 & 0.86 & 0.82 & 0.74 & 0.78 & 1.08 & 1.09 & 0.85 \\
\hline
\end{tabular}

K: ratio of mean value to the background value in Shandong.

Many studies [31-35] have shown that metals such as $\mathrm{Pb}, \mathrm{Zn}$, and $\mathrm{Cd}$ can accumulate in the soil plowing layer and migrate vertically. In Figure 2, the contents of As and $\mathrm{Cu}$ showed little change with increasing depth. The contents of $\mathrm{Cr}, \mathrm{Ni}$, and $\mathrm{Zn}$ showed little change within a depth range of $0-80 \mathrm{~cm}$, below which they tended to increase with depth, indicating the influence of the parent materials of soil. The content of $\mathrm{Pb}$ was concentrated in the surface layer of soil and decreased sharply from top to bottom, suggesting that it is mainly controlled by external environmental and anthropogenic factors. 


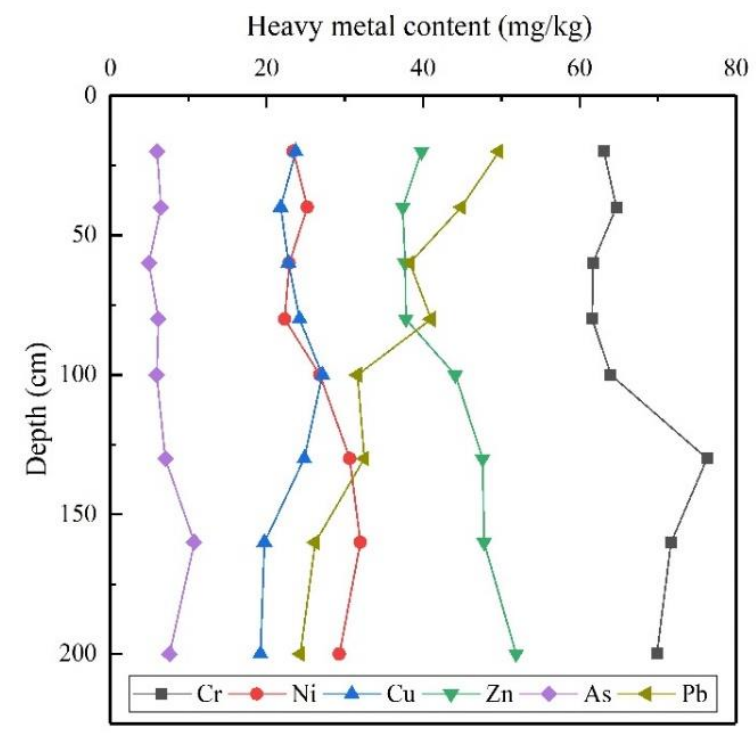

Figure 2. Contents of heavy metals (HMs) in soil profiles.

\subsubsection{Source of Heavy Metals}

The accumulation of heavy metals in soil poses a serious threat to the environment, agricultural production, and human health. Through absorption by crops, heavy metals enter the food chain, thereby threatening human health [2]. Increased concentrations of heavy metals in farmland are attributable not only to the parent material of soil, but also to human activities, such as mining, smelting, fossil fuel burning, and sewage irrigation [36,37].

The results of the KMO test $(0.715)$ and Bartlett's test $(p<0.05)$ revealed a good correlation between variables. Thus, they are suitable for FA (Table 3 ).

Table 3. Results of the KMO test and Bartlett's test.

\begin{tabular}{ccc}
\hline & \multicolumn{2}{c}{ KMO and Bartlett's Test } \\
\hline Kaiser-Meyer-Olkin Measure of Sampling Adequacy. & 0.715 \\
\hline \multirow{3}{*}{ Bartlett's Test of Sphericity } & Approx. Chi-Square & 968.005 \\
\cline { 2 - 3 } & df & 28 \\
\cline { 2 - 3 } & Sig. & 0.000 \\
\hline
\end{tabular}

The results of FA show that the initial eigenvalues of the first three factors are higher than 1 , with the cumulative contribution rate reaching $70 \%$ (Table 4 ). The contribution rate of factor 1 was $40.4 \%$, for which $\mathrm{Cr}(0.8), \mathrm{Ni}(0.86), \mathrm{Cu}(0.76), \mathrm{Zn}(0.78)$, and $\mathrm{Cd}(0.59)$ exhibited higher factor loadings. These five elements were all positively correlated with factor 1 (Table 5), indicating that they have similar distribution characteristics in soil. This indication is mainly manifested in samples 02a2, 207a, and 247c (Figure 3), with a relatively dispersed distribution, which is presumed to be affected by natural sources. The contribution rate of factor 2 was $15.8 \%$, for which $\mathrm{Pb}(0.71)$ and $\mathrm{As}(0.54)$ exhibited higher factor loadings. As shown in Figure 3, samples 250a, 295a, 296a, 296b, 297a1, and 297b, which were sampled near the town, exhibited higher factor scores. In addition, $\mathrm{Pb}$ is a characteristic feature of coal burning [38]. Therefore, factor 2 is speculated to potentially reflect anthropogenic influences. The contribution rate of factor 3 was $13.6 \%$, for which $\mathrm{Hg}(0.9)$ exhibited a higher factor loading. The factor scores of samples 70c, 94b2, 97a, 97d1, 207c, and 299d were higher (Figure 3). The Hg content (0.0081 mg/L) of farmland irrigation water near these points exceeded the standard. Thus, factor 3 is speculated to reflect the influence of farmland irrigation. 
Table 4. Explanation of total variance.

\begin{tabular}{ccccccc}
\hline \multirow{2}{*}{ Component } & \multicolumn{3}{c}{ Initial Eigenvalues } & \multicolumn{2}{c}{ Extraction Sums of Squared Loadings } \\
\cline { 2 - 6 } & Total & \% of Variance & Cumulative \% & Total & \% of Variance & Cumulative \% \\
\hline 1 & 3.232 & 40.406 & 40.406 & 3.232 & 40.406 & 40.406 \\
2 & 1.261 & 15.759 & 56.164 & 1.261 & 15.759 & \\
3 & 1.090 & 13.630 & 69.794 & 1.090 & & \\
4 & 0.789 & 9.860 & 79.654 & & \\
5 & 0.720 & 9.000 & 88.653 & & \\
6 & 0.432 & 5.404 & 94.058 & & \\
7 & 0.354 & 4.421 & 98.479 & & & \\
8 & 0.122 & 1.521 & 100.000 & & & \\
\hline
\end{tabular}

Table 5. Component matrix.

\begin{tabular}{cccc}
\hline \multirow{2}{*}{ Heavy Metal } & \multicolumn{3}{c}{ Component } \\
\cline { 2 - 4 } & $\mathbf{1}$ & $\mathbf{2}$ & $\mathbf{3}$ \\
\hline $\mathrm{Cr}$ & $\mathbf{0 . 8 0 4}$ & -0.457 & -0.062 \\
$\mathrm{Ni}$ & $\mathbf{0 . 8 6 0}$ & -0.284 & -0.205 \\
$\mathrm{Cu}$ & $\mathbf{0 . 7 5 5}$ & 0.276 & -0.185 \\
$\mathrm{Zn}$ & $\mathbf{0 . 7 7 9}$ & -0.239 & 0.214 \\
$\mathrm{As}$ & 0.414 & $\mathbf{0 . 5 4 4}$ & -0.122 \\
$\mathrm{Cd}$ & $\mathbf{0 . 5 8 6}$ & 0.132 & 0.350 \\
$\mathrm{Hg}$ & 0.103 & 0.137 & $\mathbf{0 . 9 0 1}$ \\
$\mathrm{Pb}$ & 0.382 & $\mathbf{0 . 7 1 1}$ & -0.123 \\
\hline
\end{tabular}

Bold data show higher factor loadings.
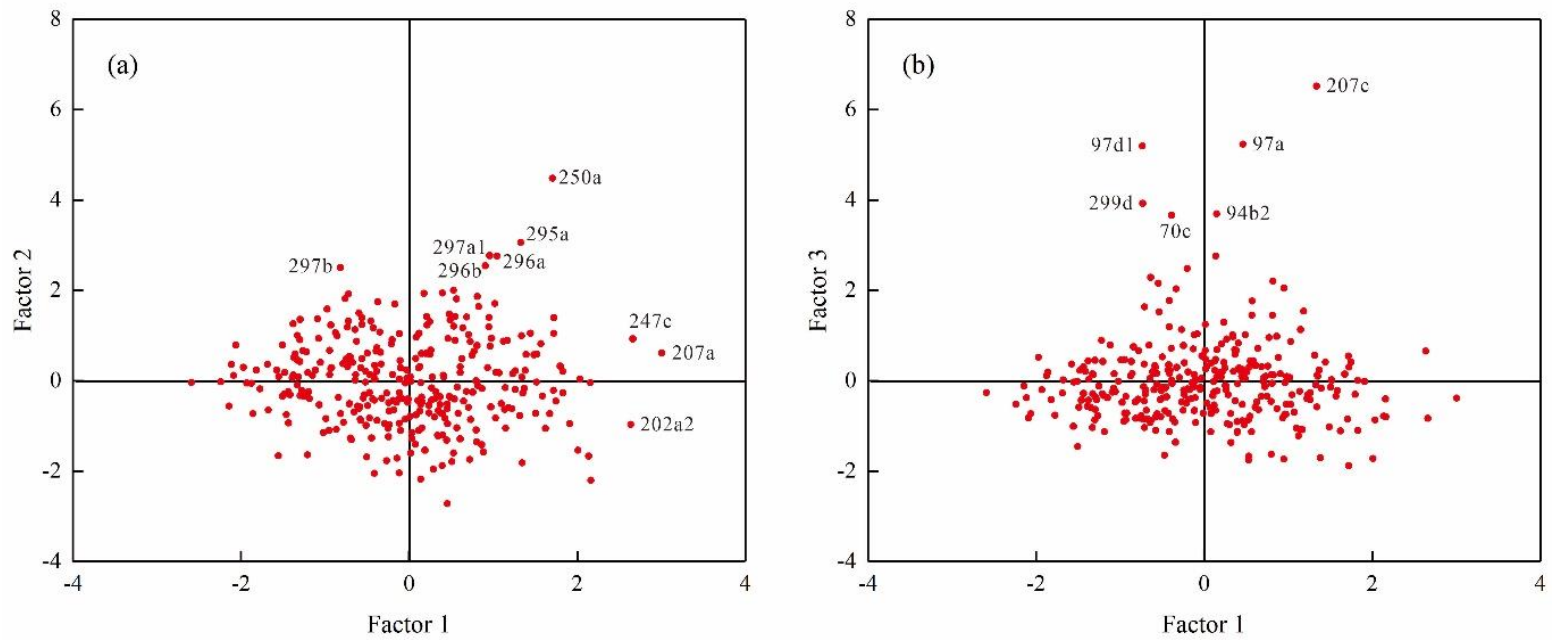

Figure 3. Scatter diagram of FA: (a) Factor 1 vs. Factor 2; (b) Factor 1 vs. Factor 3.

To further reveal the correlation between heavy metals, HCA was conducted on eight heavy metal elements in soil. The results are shown in Figure 4. Based on the results, the eight heavy metals can be divided into three clusters at a rescaled distance of 22. $\mathrm{Cr}, \mathrm{Ni}, \mathrm{Cu}$, $\mathrm{Zn}$, and $\mathrm{Cd}$ belong to cluster $1, \mathrm{~Pb}$ and As belong to cluster 2, and $\mathrm{Hg}$ belongs to cluster 3 . This classification is basically consistent with the FA results. 


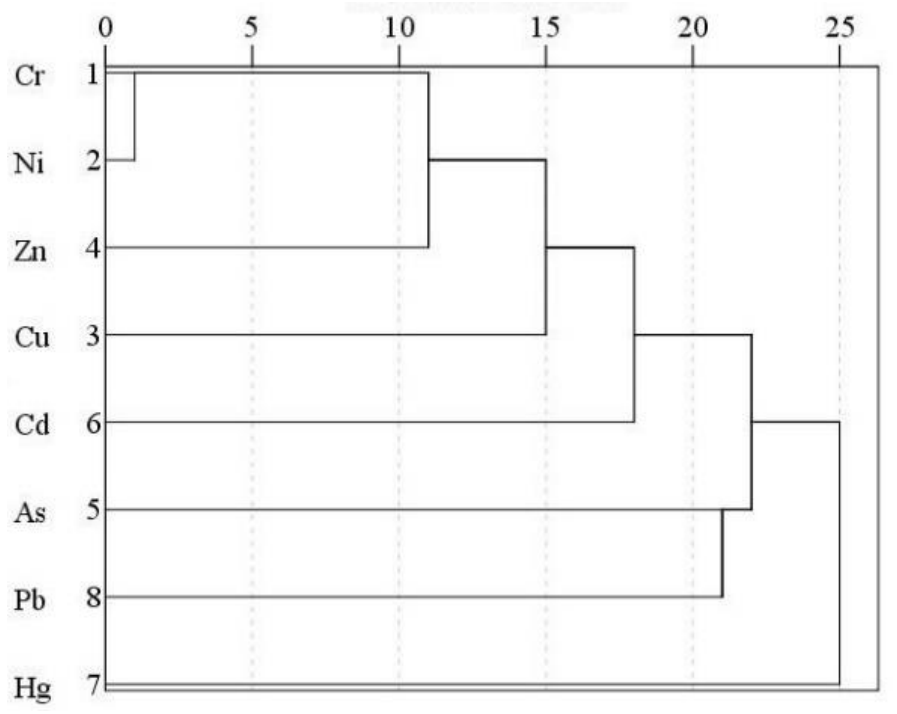

Figure 4. Dendrogram of HCA.

\subsection{Average Concentration of Heavy Metals in Ginger and Root-Soil}

When the concentration of heavy metals in animals and plants exceeds a certain threshold, they cause harm. In particular, heavy metals enter the human body through the food chain and accumulate continuously, increasing the risk of cancer and other diseases. Therefore, it is important to study the content characteristics of heavy metals in crops. Such studies would contribute towards controlling the quality of crops, as well as characterizing the absorption intensity of heavy metals in soil by crops.

The average concentrations of heavy metals in ginger followed the order: $\mathrm{Zn}>\mathrm{Cu}>$ $\mathrm{Ni}>\mathrm{Cr}>\mathrm{Pb}>\mathrm{As}>\mathrm{Cd}>\mathrm{Hg}$ (Table 6). $\mathrm{Hg}$ was not detected in the samples. Half of the detection limit was used for statistics. The $\mathrm{CV}$ values of $\mathrm{Zn}$ and As were 0.26 and 0.31 , respectively, indicating uniform distribution. The $\mathrm{CV}$ values of $\mathrm{Cu}, \mathrm{Ni}, \mathrm{Pb}, \mathrm{Cr}$, and $\mathrm{Cd}$ ranged from 0.41 to 0.74 , indicating uneven distribution.

Table 6. Statistical characteristics of heavy metal contents in ginger (mg/kg).

\begin{tabular}{ccccccccc}
\hline Data & $\mathbf{C r}$ & $\mathbf{N i}$ & $\mathbf{C u}$ & $\mathbf{Z n}$ & $\mathbf{A s}$ & $\mathbf{C d}$ & $\mathbf{H g}$ & $\mathbf{P b}$ \\
\hline $\begin{array}{c}\text { Sample } \\
\text { number }\end{array}$ & 18 & 18 & 18 & 18 & 18 & 18 & 18 & 18 \\
Mean & 0.52 & 0.55 & 0.84 & 2.36 & 0.02 & 0.0096 & 0.0015 & 0.04 \\
Minimum & 0.11 & 0.27 & 0.51 & 1.34 & 0.01 & 0.0025 & 0.0015 & 0.01 \\
Maximum & 1.68 & 1.20 & 2.05 & 3.46 & 0.03 & 0.0280 & 0.0015 & 0.09 \\
CV & 0.72 & 0.46 & 0.41 & 0.26 & 0.31 & 0.74 & 0.00 & 0.51 \\
BCF & 0.0066 & 0.0184 & 0.0267 & 0.0343 & 0.0024 & 0.0687 & 0.0335 & 0.0013 \\
\hline
\end{tabular}

The average concentration of heavy metals in root-soil followed the order: $\mathrm{Cr}>\mathrm{Zn}>$ $\mathrm{Pb}>\mathrm{Cu}>\mathrm{Ni}>\mathrm{As}>\mathrm{Cd}>\mathrm{Hg}$ (Table 7). The CV values of $\mathrm{Cr}, \mathrm{Ni}, \mathrm{As}, \mathrm{Zn}, \mathrm{Pb}, \mathrm{Cu}$, and $\mathrm{Hg}$ were between 0.17 and 0.28 , indicating relatively uniform distribution; the $C V$ value of $C d$ was 0.55 , suggesting uneven distribution.

Different heavy metals show different levels of enrichment in plants. As shown in Table 7, the $B C F$ values followed the order: $\mathrm{Cd}>\mathrm{Zn}>\mathrm{Hg}>\mathrm{Cu}>\mathrm{Ni}>\mathrm{Cr}>\mathrm{As}>\mathrm{Pb}$. In general, $\mathrm{Cd}$ and $\mathrm{Zn}$ have greater potential for enrichment in ginger compared to $\mathrm{Cr}$, As, Dand $\mathrm{Pb}$. The $B C F$ value of $\mathrm{Cd}$ was 53 times that of $\mathrm{Pb}$. The chemical properties of heavy metals are one of the important factors affecting their migration and enrichment in the soil-ginger system. 
Table 7. Statistical characteristics of heavy metal contents in root-soil (mg/kg).

\begin{tabular}{ccccccccc}
\hline Data & $\mathbf{C r}$ & $\mathbf{N i}$ & $\mathbf{C u}$ & $\mathbf{Z n}$ & $\mathbf{A s}$ & $\mathbf{C d}$ & $\mathbf{H g}$ & $\mathbf{P b}$ \\
\hline Sample & 18 & 18 & 18 & 18 & 18 & 18 & 18 & 18 \\
number & & & & & & & & \\
Mean & 79.49 & 29.81 & 31.31 & 68.81 & 7.43 & 0.14 & 0.04 & 31.83 \\
Minimum & 57.90 & 19.70 & 23.30 & 44.80 & 5.50 & 0.07 & 0.02 & 25.10 \\
Maximum & 93.70 & 40.30 & 51.00 & 105.00 & 9.59 & 0.38 & 0.07 & 49.70 \\
CV & 0.12 & 0.17 & 0.22 & 0.20 & 0.17 & 0.55 & 0.28 & 0.21 \\
\hline
\end{tabular}

The positive and negative correlations between elements in plants reveal their synergistic and antagonistic effects, respectively. Table 8 shows a significant positive correlation between $\mathrm{Cr}, \mathrm{Ni}$, and $\mathrm{Cd}$ in ginger, indicating that these three heavy metals co-operate with each other to promote absorption. No obvious correlation was observed among the other heavy metals.

Table 8. Correlation analysis of heavy metal contents in ginger.

\begin{tabular}{cccccccc}
\hline Heavy Metal & $\mathbf{C r}$ & $\mathbf{N i}$ & $\mathbf{C u}$ & $\mathbf{Z n}$ & $\mathbf{A s}$ & $\mathbf{C d}$ & $\mathbf{P b}$ \\
\hline $\mathrm{Cr}$ & 1 & $0.790^{* *}$ & 0.197 & 0.362 & 0.114 & $0.498^{*}$ & 0.331 \\
$\mathrm{Ni}$ & & 1 & 0.356 & 0.091 & -0.015 & $0.672^{* *}$ & 0.373 \\
$\mathrm{Cu}$ & & & 1 & 0.166 & -0.271 & 0.331 & 0.238 \\
$\mathrm{Zn}$ & & & & 1 & 0.172 & 0.268 & 0.119 \\
$\mathrm{As}$ & & & & & 1 & 0.044 & 0.050 \\
$\mathrm{Cd}$ & & & & & & & 0.162 \\
$\mathrm{~Pb}$ & & & & & & & 1 \\
\hline
\end{tabular}

** Correlation is significant at the 0.01 level (2-tailed). ${ }^{*}$ Correlation is significant at the 0.05 level (2-tailed).

\subsection{Health Risk Assessment of Heavy Metals}

\subsubsection{Pollution Assessment for Heavy Metal Pollution in Soil}

The content of heavy metals in surface soil of the study area did not exceed the risk control standard for soil contamination of agricultural land (GB 15618-2018) (Figure 5). Therefore, surface soil of the study area meets the second-level national requirements for soil environmental quality. It is highly important to use appropriate methods for evaluating the degree of heavy metal pollution in soil to control ecological and environmental pollution. In this study, according to background values of heavy metals in the study area and risk screening values for soil contamination of agricultural land, the calculated $P_{i}$ values $(0.07-0.45)$ were all below 0.7 , and $I_{g e o}$ values (from -0.46 to -1.01 ) were all below 0 . Except for $\mathrm{Hg}$ (43.37), $E_{i}$ values (0.82-23.46) of the other heavy metals were all below 40. The calculated RI value (91.59) was less than 150 (Table 9). According to these results, there is basically no heavy metal pollution in the soil of the study area.

Table 9. Values of $P_{i}, I_{g e o}, E_{i}$, and $R I$.

\begin{tabular}{ccccc}
\hline & $\boldsymbol{P}_{\boldsymbol{i}}$ & $\boldsymbol{I}_{\text {geo }}$ & $\boldsymbol{E}_{\boldsymbol{i}}$ & $\boldsymbol{R} \boldsymbol{I}$ \\
\hline $\mathrm{Cr}$ & 0.45 & -0.47 & 2.16 & \\
$\mathrm{Ni}$ & 0.36 & -0.70 & 4.62 & \\
$\mathrm{Cu}$ & 0.39 & -0.80 & 4.29 & 91.59 \\
$\mathrm{Zn}$ & 0.26 & -0.88 & 0.82 & \\
$\mathrm{As}$ & 0.16 & -1.01 & 7.44 & \\
$\mathrm{Cd}$ & 0.34 & -0.94 & 23.46 & \\
$\mathrm{Hg}$ & 0.07 & -0.47 & 43.37 & \\
$\mathrm{~Pb}$ & 0.28 & -0.46 & 5.43 & \\
\hline
\end{tabular}




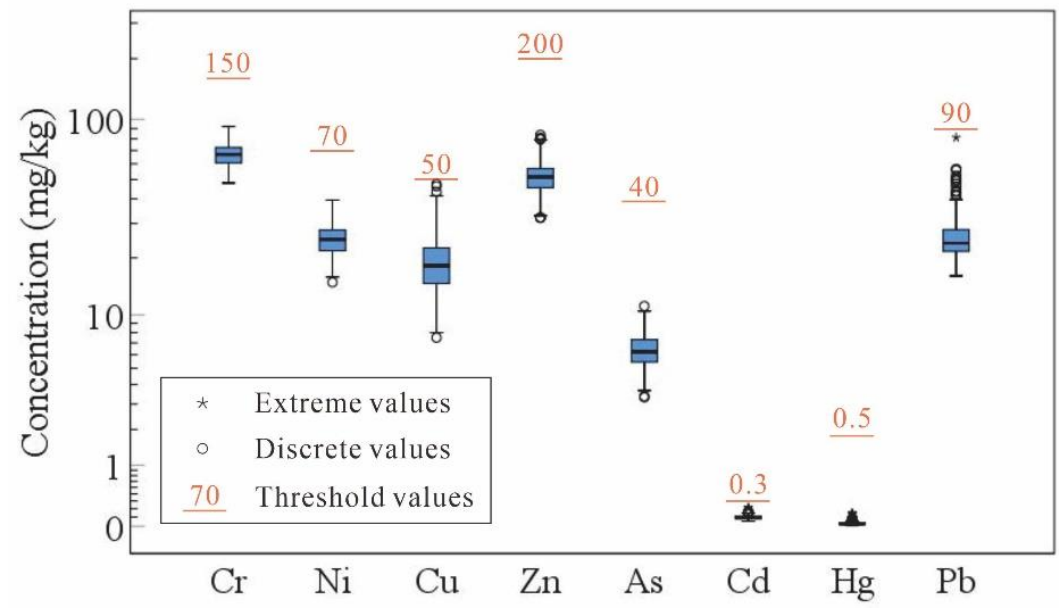

Figure 5. Box plot of heavy metal contents in surface soil.

\subsubsection{Safety Assessment of Ginger}

The heavy metal safety of ginger in the study area was assessed according to the limits of $\mathrm{As}, \mathrm{Cd}, \mathrm{Cr}, \mathrm{Hg}$, and Pb stipulated in the People's Republic of China "National Food Safety Standard Contamination Limit in Food" (GB 2762-2017), and limits of Cu and Zn stipulated in the People's Republic of China agricultural industry standards "Limits of Eight Elements in Cereals, Legume, Tubers and its Products" (NY 861-2004). The results showed that six ginger samples contained excessive $\mathrm{Cr}$ contents, with an exceeding rate of $33 \%$. None of the other heavy metals exceeded the standard (Figure 6). Although previous analyses showed that the enrichment of $\mathrm{Cr}$ is weak in ginger, the content of $\mathrm{Cr}$ in soil was the highest among the eight heavy metals. Thus, the enrichment of $\mathrm{Cr}$ in soil significantly increases the risk of excessive $\mathrm{Cr}$ in ginger.

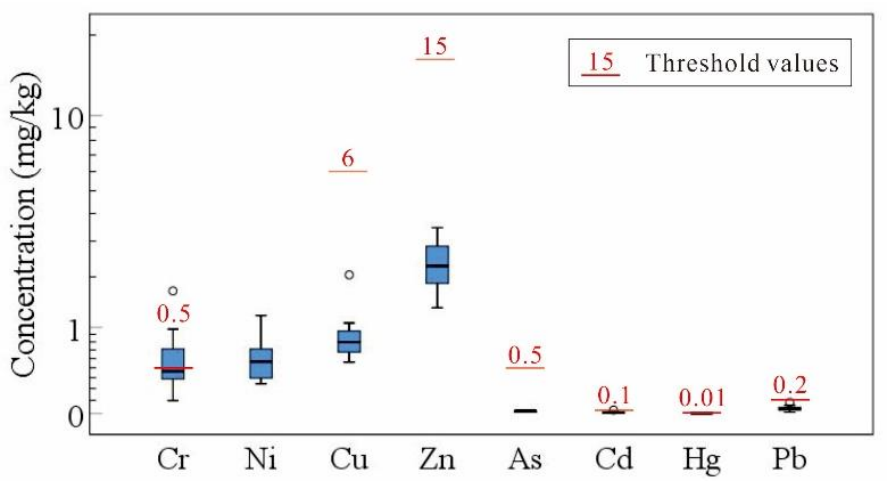

Figure 6. Box plot of heavy metal contents in ginger.

\section{Conclusions}

In this study, the characteristics, sources, and health risks of heavy metals in a soilginger system in the Jing River Basin were investigated. The content of $\mathrm{Cr}$ in surface soil was the highest, reaching $66.92 \mathrm{mg} / \mathrm{kg}$, and the content of $\mathrm{Hg}$ was the lowest at $0.03 \mathrm{mg} / \mathrm{kg}$. The $\mathrm{CV}$ value of $\mathrm{Hg}$ was 0.57 , indicating a relatively uneven distribution. The $\mathrm{CV}$ values of the other heavy metals ranged from 0.12 to 0.37 , indicating a relatively uniform distribution. In the soil profile, the contents of $\mathrm{As}$ and $\mathrm{Cu}$ showed little change, while those of $\mathrm{Cr}, \mathrm{Ni}$, $\mathrm{Zn}$, and As increased with depth within a depth range of $80-200 \mathrm{~cm}$. Pb was concentrated only in the surface layer of soil, which may be attributable to external environmental and anthropogenic factors. The results of factor analysis (FA) and hierarchical clustering analysis (HCA) showed that the contents of $\mathrm{Cr}, \mathrm{Ni}, \mathrm{Cu}, \mathrm{Zn}$, and $\mathrm{Cd}$ in soil may be affected by the parent materials of soil, those of $\mathrm{Pb}$ and As by human activities, and that of $\mathrm{Hg}$ 
by irrigation water. The calculated results of $P_{i}(0.07-0.45), I_{\text {geo }}$ (from -0.46 to -1.01$), E_{i}$ (0.82-43.37), and RI (91.59) show that the soil in the study area is not polluted by heavy metals. $\mathrm{Cd}$ and $\mathrm{Zn}$ have potential for enrichment in ginger, with $B C F$ values of 0.0687 and 0.0343 , respectively. The BCF value of $\mathrm{Cr}(0.0066)$ was relatively small, but the $\mathrm{Cr}$ content in ginger exceeded the limit, possibly because $\mathrm{Cr}$ has the highest content in soil among the eight heavy metals.

Author Contributions: Conceptualization, S.W., Z.G. and Y.Z.; methodology, S.W. and Y.Z.; software, Y.Z.; formal analysis, S.W. and Y.Z.; investigation, S.W., H.Z., Z.W., B.J. and Y.L.; data curation, Y.Z. and H.D.; writing —original draft preparation, S.W. and Y.Z.; writing—review and editing, S.W., Z.G. and Y.Z.; project administration, S.W., Z.G. and Y.Z. All authors have read and agreed to the published version of the manuscript.

Funding: This research was supported by the Geological Exploration and Scientific and Technological Innovation Project of Shandong Provincial Bureau of Geology and Mineral Resources (202005) and the Research on Major Geological Environmental Issues in Coastal Zone of Shandong Province (KY201911).

Data Availability Statement: The data presented in this study are available on request from the corresponding author. The data are not publicly available because the project team do not allow us to publish the data of this study.

Conflicts of Interest: The authors declare no conflict of interest.

\section{References}

1. Luque-Espinar, J.; Pardo-Igúzquiza, E.; Grima-Olmedo, J. Multiscale analysis of the spatial variability of heavy metals and organic matter in soils and groundwater across Spain. J. Hydrol. 2018, 561, 348-371. [CrossRef]

2. Xu, L.; Lu, A.; Wang, J.; Ma, Z.; Pan, L.; Feng, X.; Luan, Y. Accumulation status, sources and phytoavailability of metals in greenhouse vegetable production systems in Beijing, China. Ecotoxicol. Environ. Saf. 2015, 122, 214-220. [CrossRef] [PubMed]

3. Li, T.; Song, Y.; Yuan, X.; Li, J.; Ji, J.; Fu, X.; Zhang, Q.; Guo, S. Incorporating Bioaccessibility into Human Health Risk Assessment of Heavy Metals in Rice (Oryza sativa L.): A Probabilistic-Based Analysis. J. Agric. Food Chem. 2018, 66, 5683-5690. [CrossRef] [PubMed]

4. Gabarrón, M.; Faz, A.; Acosta, J. Use of multivariable and redundancy analysis to assess the behavior of metals and arsenic in urban soil and road dust affected by metallic mining as a base for risk assessment. J. Environ. Manag. 2018, 206, 192-201. [CrossRef] [PubMed]

5. Heidarieh, M.; Maragheh, M.G.; Shamami, M.A.; Behgar, M.; Ziaei, F.; Akbari, Z. Evaluate of heavy metal concentration in shrimp (Penaeus semisulcatus) and crab (Portunus pelagicus) with INAA method. SpringerPlus 2013, 2, 72. [CrossRef]

6. Matloob, M. Using Stripping Voltammetry to Determine Heavy Metals in Cooking Spices Used in Iraq. Pol. J. Environ. Stud. 2016, 25, 2057-2070. [CrossRef]

7. Han, Q.; Wang, M.; Cao, J.; Gui, C.; Liu, Y.; He, X.; He, Y.; Liu, Y. Health risk assessment and bioaccessibilities of heavy metals for children in soil and dust from urban parks and schools of Jiaozuo, China. Ecotoxicol. Environ. Saf. 2020, 191, 110157. [CrossRef] [PubMed]

8. Chen, F.; Wang, Q.; Meng, F.; Chen, M.; Wang, B. Effects of long-term zinc smelting activities on the distribution and health risk of heavy metals in agricultural soils of Guizhou province, China. Environ. Geochem. Health 2020, 1-16. [CrossRef]

9. Wang, Y.; Duan, X.; Wang, L. Spatial distribution and source analysis of heavy metals in soils influenced by industrial enterprise distribution: Case study in Jiangsu Province. Sci. Total Environ. 2020, 710, 134953. [CrossRef]

10. Gan, Y.; Miao, Y.; Wang, L.-H.; Yang, G.; Li, Y.C.; Wang, W.; Dai, J. Source Contribution Analysis and Collaborative Assessment of Heavy Metals in Vegetable-Growing Soils. J. Agric. Food Chem. 2018, 66, 10943-10951. [CrossRef]

11. Huang, H.; Lin, C.; Yu, R.; Yan, Y.; Hu, G.; Li, H. Contamination assessment, source apportionment and health risk assessment of heavy metals in paddy soils of Jiulong River Basin, Southeast China. RSC Adv. 2019, 9, 14736-14744. [CrossRef]

12. Sun, L. Migration and Source Analysis of Metals in Soil-Tea Plant System of Tieguanyin Tea Garden. Ph.D. Thesis, Huaqiao University, Quanzhou, China, 2020.

13. Zhang, X.; Yang, H.; Cui, Z. Evaluation and analysis of soil migration and distribution characteristics of heavy metals in iron tailings. J. Clean. Prod. 2018, 172, 475-480. [CrossRef]

14. Müller, G. Schwermetalle in sedimenten des staugeregelten Neckars. Nature 1969, 79, 778-783.

15. Hakanson, L. An ecological risk index for aquatic pollution control-A sediment logical approach. Water Res. 1980, 14, 975-1001. [CrossRef]

16. Li, Z.; Ma, Z.; van der Kuijp, T.J.; Yuan, Z.; Huang, L. A review of soil heavy metal pollution from mines in China: Pollution and health risk assessment. Sci. Total Environ. 2014, 468-469, 843-853. [CrossRef] 
17. Sun, Y.; Zhou, Q.; Xie, X.; Liu, R. Spatial, sources and risk assessment of heavy metal contamination of urban soils in typical regions of Shenyang, China. J. Hazard. Mater. 2010, 174, 455-462. [CrossRef]

18. Hu, B.; Shao, S.; Ni, H.; Fu, Z.; Hu, L.; Zhou, Y.; Min, X.; She, S.; Chen, S.; Huang, M.; et al. Current status, spatial features, health risks, and potential driving factors of soil heavy metal pollution in China at province level. Environ. Pollut. 2020, $266,114961$. [CrossRef]

19. Baruah, S.G.; Ahmed, I.; Das, B.; Ingtipi, B.; Boruah, H.; Gupta, S.K.; Nema, A.K.; Chabukdhara, M. Heavy metal(loid)s contamination and health risk assessment of soil-rice system in rural and peri-urban areas of lower brahmaputra valley, northeast India. Chemosphere 2021, 266, 129150. [CrossRef] [PubMed]

20. Gujre, N.; Mitra, S.; Soni, A.; Agnihotri, R.; Rangan, L.; Rene, E.R.; Sharma, M.P. Speciation, contamination, ecological and human health risks assessment of heavy metals in soils dumped with municipal solid wastes. Chemosphere 2021, 262, 128013. [CrossRef]

21. Mirzaei, M.; Marofi, S.; Solgi, E.; Abbasi, M.; Karimi, R.; Bakhtyari, H.R.R. Ecological and health risks of soil and grape heavy metals in long-term fertilized vineyards (Chaharmahal and Bakhtiari province of Iran). Environ. Geochem. Health 2019, $42,27-43$. [CrossRef]

22. Zhang, W.; Liu, M.; Li, C. Soil heavy metal contamination assessment in the Hun-Taizi River watershed, China. Sci. Rep. 2020, 10, 8730. [CrossRef] [PubMed]

23. Goroya, K.G.; Mitiku, Z.; Asresahegn, Y.A. Determination of concentration of heavy metals in ginger using flame atomic absorption spectroscopy. Afr. J. Plant. Sci. 2019, 13, 163-167.

24. Li, Y.; Xu, K. Effect of Soil Lead Content on Growth and Product Safety of Ginger. Shandong. Agr. Sci. 2011, 9, 65-68.

25. Karimian, S.; Shekoohiyan, S.; Moussavi, G. Health and ecological risk assessment and simulation of heavy metal-contaminated soil of Tehran landfill. RSC Adv. 2021, 11, 8080-8095. [CrossRef]

26. Ding, C.; Ma, Y.; Li, X.; Zhang, T.; Wang, X. Derivation of soil thresholds for lead applying species sensitivity distribution: A case study for root vegetables. J. Hazard. Mater. 2016, 303, 21-27. [CrossRef] [PubMed]

27. Peng, M.; Zhao, C.; Ma, H.; Yang, Z.; Yang, K.; Liu, F.; Li, K.; Yang, Z.; Tang, S.; Guo, F.; et al. Heavy metal and Pb isotopic compositions of soil and maize from a major agricultural area in Northeast China: Contamination assessment and source apportionment. J. Geochem. Explor. 2020, 208, 106403. [CrossRef]

28. Rezapour, S.; Atashpaz, B.; Moghaddam, S.S.; Kalavrouziotis, I.K.; Damalas, C.A. Cadmium accumulation, translocation factor, and health risk potential in a wastewater-irrigated soil-wheat (Triticum aestivum L.) system. Chemosphere 2019, 231, 579-587. [CrossRef]

29. Garg, V.K.; Yadav, P.; Mor, S.; Singh, B.; Pulhani, V. Heavy Metals Bioconcentration from Soil to Vegetables and Assessment of Health Risk Caused by Their Ingestion. Biol. Trace Elem. Res. 2014, 157, 256-265. [CrossRef]

30. Melgar, M.J.; Alonso, J.; García, M.A. Cadmium in edible mushrooms from NW Spain: Bioconcentration factors and consumer health implications. Food Chem. Toxicol. 2016, 88, 13-20. [CrossRef]

31. Zheng, G. The Vertical Distribution Regularity of Heavy Metal Elements in Guanzhong Tier Soil Profile. Acta Geosci. Sin. 2008, 29, 109-115.

32. Hou, Q.; Yang, Z.; Yang, X.; Yang, Y.; Lai, M. Study of distribution of geochemical speciation of cadmium and factors controlling the distribution in paddy soil profiles, Chengdu Plain, Southwest China. Earth. Sci. Front. 2008, 15, 36-46.

33. Xiang, M.; Zhang, G.-P.; Li, L.; Wei, X.-F.; Cai, Y.-B. Characteristics of heavy metals in soil profile and pore water around Hechi antimony-lead smelter, Guangxi, China. Huan Jing Ke Xue 2012, 33, 266-272. [PubMed]

34. Zhang, Q.; Han, G.; Liu, M.; Li, X.; Wang, L.; Liang, B. Distribution and Contamination Assessment of Soil Heavy Metals in the Jiulongjiang River Catchment, Southeast China. Int. J. Environ. Res. Public Health 2019, 16, 4674. [CrossRef]

35. Wang, Y.; Chen, Y.; Li, Z. Contamination pattern of heavy metals in Chinese urban soils. Environ. Chem. 2012, 31, 763-770.

36. Säumel, I.; Kotsyuk, I.; Hölscher, M.; Lenkereit, C.; Weber, F.; Kowarik, I. How healthy is urban horticulture in high traffic areas? Trace metal concentrations in vegetable crops from plantings within inner city neighbourhoods in Berlin, Germany. Environ. Pollut. 2012, 165, 124-132. [CrossRef] [PubMed]

37. Cao, C.; Chen, X.-P.; Ma, Z.-B.; Jia, H.-H.; Wang, J.-J. Greenhouse cultivation mitigates metal-ingestion-associated health risks from vegetables in wastewater-irrigated agroecosystems. Sci. Total Environ. 2016, 560-561, 204-211. [CrossRef]

38. Zhang, Y. Chemical Composition and $\mathrm{Pb}$, Sr Isotopes Tracing of $\mathrm{PM}_{2.5}$ in Quanzhou. Ph.D. Thesis, Huaqiao University, Quanzhou, China, 2017. 